\title{
Correction to: Linking place records using multi-view encoders
}

\section{Vinícius Cousseau ${ }^{1} \cdot$ Luciano Barbosa $^{2}$}

Published online: 16 May 2021

(c) Springer-Verlag London Ltd., part of Springer Nature 2021

\section{Correction to: Neural Computing and Applications} https://doi.org/10.1007/s00521-021-05932-9

In the Original article, the author name is wrong. It is modified from Vincius Cousseau to Vinícius Cousseau. And, in the Page 12. Figure 3. (a): Fix typing error in image subtitle (Summary is typed as Sumary).
Publisher's Note Springer Nature remains neutral with regard to jurisdictional claims in published maps and institutional affiliations.

The original article can be found online at https:// doi.org/10.1007/s00521-021-05932-9.

Luciano Barbosa

luciano@cin.ufpe.br

Vinícius Cousseau

vinicius.cousseau@incognia.com

1 Incognia, Palo Alto, CA, USA

2 Universidade Federal de Pernambuco, Recife, Pernambuco, Brazil 